\title{
0597. The relation between intestinal intramucosal ph and stress hormones in pig hemorrhagic shock model
}

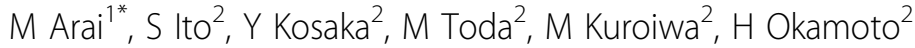 \\ From ESICM LIVES 2014 \\ Barcelona, Spain. 27 September - 1 October 2014
}

\section{Introduction}

It is known that intestinal intramucosal $\mathrm{pH}(\mathrm{pHi})$ is a good parameter of tissue perfusion in critical patients. However, physiological meaning of $\mathrm{pHi}$ value related to other physiological parameter, such as stress hormone, is not well known. The purpose of the study is to clarify the importance of monitoring pHi during hemorrhagic shock in pig model. The relation between pHi, oxygen supply and demand balance at intestinal region and stress hormones are discussed.

\section{Methods}

The studies were performed on 6 pigs (body weight $25 \pm$ $4 \mathrm{~kg}$ ). Anesthesia was induced by inhalation of isoflurane 3-5\% and after endotracheal intubation, pigs were placed on a positive pressure ventilation. Anesthesia was maintained with pancronium and isoflurane $2 \%$. A catheter was inserted through carotid artery to measure aortic blood pressure and to sample blood. Ringer's Lactated solution was infused throughout the experiment at $10 \mathrm{ml} / \mathrm{kg} / \mathrm{hr}$. The pig's abdomen was opened through a midline incision and the electromagnetic flow probe was placed on the root of superior mesenteric artery (SMA). Tonomitor ${ }^{\circledR}$ (Tonometrics) was inserted from antimesentric region of jejunum. A polyvinyl tube was inserted to superior mesenteric vein (SMV) to sample blood.

Protocol: Control data were obtained after $30 \mathrm{~min}$ stabilization period (Baseline; S1). Then the pigs were bled gradually and MAP was maintained at $40 \mathrm{mmHg}$ for 1 hours (Shock Phase; S2). Pigs were resuscitated with whole blood (Resuscitation Phase 1; S3). Additional 1 hour was evaluated for post-resuscitation phase (S4).

${ }^{1}$ Kitasato University, Anesthesia and Intensive Care Medicine, Sagamihara, Japan

Full list of author information is available at the end of the article
Measurements: Jejunal pHi was calculated by the luminal PCO2, obtained with a balloon tonometer, and arterial bicarbonate concentration. Arterial blood samples were taken for analysis of adrenaline (ADR), noradrenaline (NA), angiotensin II (Ang II) and arterial blood gas. SMV blood samples were taken for analysis of lactate/ pylvate acid (sma L/P), and blood gas (PsmvCO2).

\section{Results}

At shock phase, SMA flow decreased to $40 \%$ from the baseline $(\mathrm{p}<0.01)$ and $\mathrm{pHi}$ decreased from $7.4 \pm 0.2$ to

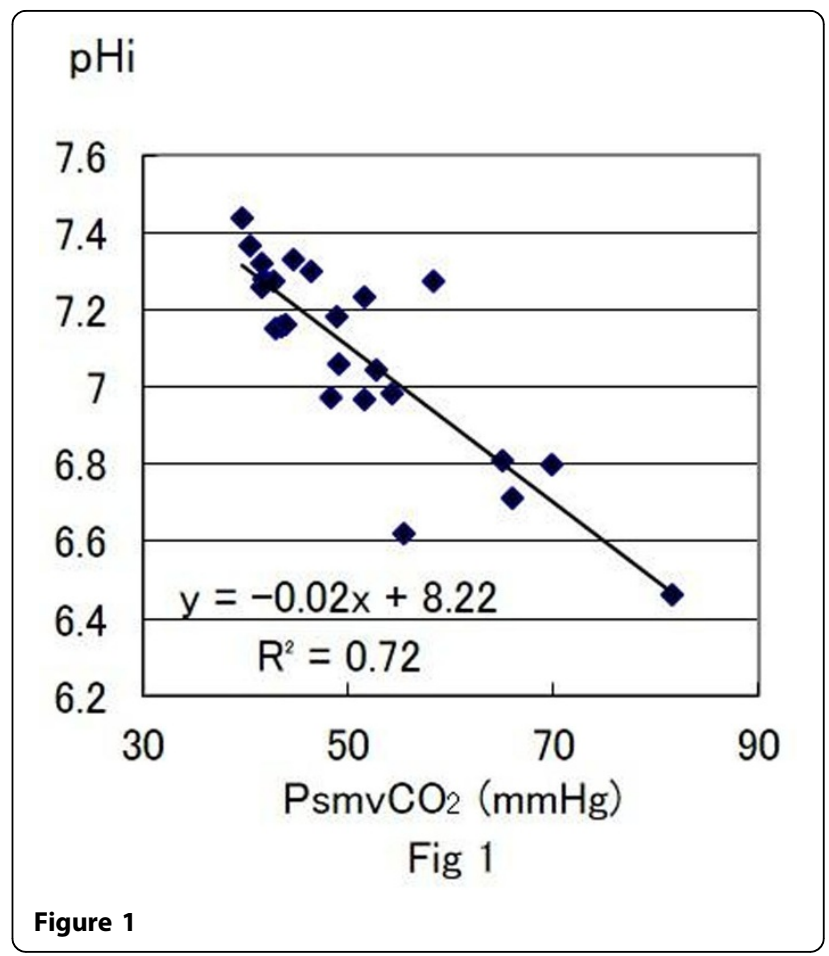




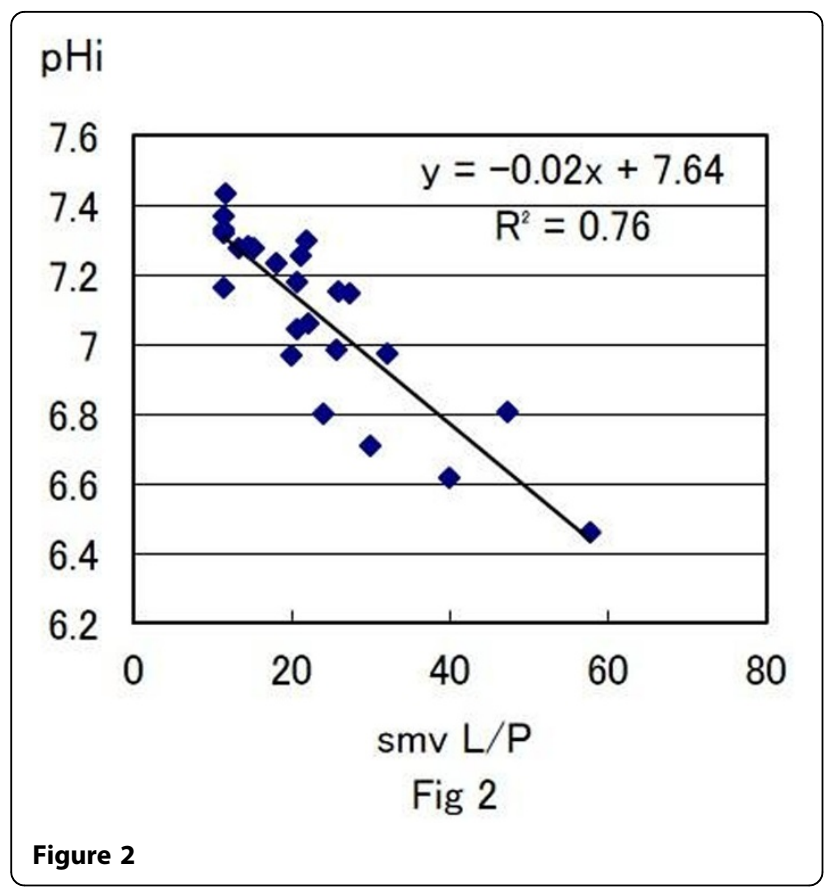

$6.8 \pm 0.2(\mathrm{p}<0.01)$. The correlation between $\mathrm{pHi}$ and other parameters are as follows, $\mathrm{pHi}$ vs PsmvCO2; $\mathrm{y}=$ $-0.02 \mathrm{x}+8.22(\mathrm{r} 2=0.72)($ Fig 1$), \mathrm{pHi}$ vs smv $\mathrm{L} / \mathrm{P} ; \mathrm{y}=$ $-0.02 \mathrm{x}+7.64(\mathrm{r} 2=0.76)($ Fig 2$)$, pHi vs ADR $(\mathrm{pg} / \mathrm{ml})$; $\mathrm{y}=-0.09 \ln (\mathrm{x})+7.74(\mathrm{r} 2=0.72), \mathrm{pHi}$ vs NA $(\mathrm{pg} / \mathrm{ml}) ; \mathrm{y}=-$ $0.09 \ln (\mathrm{x})+7.79(\mathrm{r} 2=0.74)$, pHi vs Ang II $(\mathrm{pg} / \mathrm{ml}) ; \mathrm{y}=$ $-0.11 \ln (\mathrm{x})+7.71(\mathrm{r} 2=0.75)$.

\section{Discussion}

Changes of $\mathrm{pHi}$ value during hemorrhagic shock was correlated with PsmvCO2, smv L/P and stress hormones (ADR, NA, Ang II). It is considered that change in $\mathrm{pHi}$ show the anaerobic metabolism status of the intestinal tissue which indicate tissue hypoxia of the intestine induced by hemorrhagic shock and increase in sympathetic nerve activity. pHi was strongly correlated to other physiological parameters which indicate that $\mathrm{pHi}$ is significance parameter of hemorrhagic shock.

\section{Conclusions}

pHi is significant parameter of tissue hypoperfusion and sympathetic nerve activity during hemorrhagic shock.

\section{Authors' details}

${ }^{1}$ Kitasato University, Anesthesia and Intensive Care Medicine, Sagamihara, Japan. ${ }^{2}$ Kitasato University, School of Medicine, Anesthesiology, Sagamihara, Japan.

Published: 26 September 2014
doi:10.1186/2197-425X-2-S1-P40

Cite this article as: Arai et al:: 0597. The relation between intestinal intramucosal ph and stress hormones in pig hemorrhagic shock model. Intensive Care Medicine Experimental 2014 2(Suppl 1):P40.

\section{Submit your manuscript to a SpringerOpen ${ }^{\circ}$ journal and benefit from:}

- Convenient online submission

- Rigorous peer review

- Immediate publication on acceptance

- Open access: articles freely available online

- High visibility within the field

- Retaining the copyright to your article

Submit your next manuscript at $>$ springeropen.com 